\title{
Correction to: Myricetin improves endurance capacity by inducing muscle fiber type conversion via miR-499
}

Luting Wu, Li Ran, Hedong Lang, Min Zhou, Li Yu, Long Yi, Jundong Zhu, Lei Liu* and Mantian Mi*

\section{Correction to: Wu et al. Nutr Metab (Lond) (2019) 16:27 https://doi.org/10.1186/s12986-019-0353-8}

Following publication of the original article [1], the authors identified errors in Figs. 2 and 3. The correct figures are given below.

The author group has been updated above and the original article [1] has been corrected.

Published online: 03 June 2021

The original article can be found online at https://doi.org/10.1186/s12986019-0353-8

*Correspondence: liuleililian@icloud.com; mi_mt2009@hotmail.com

Research Center for Nutrition and Food Safety, Chongqing Key Laboratory of Nutrition and Food Safety, Institute of Military Preventive Medicine,

Third Military Medical University, Chongqing, China

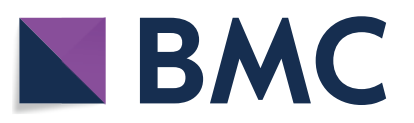

(c) The Author(s) 2021. This article is licensed under a Creative Commons Attribution 4.0 International License, which permits use, sharing, adaptation, distribution and reproduction in any medium or format, as long as you give appropriate credit to the original author(s) and the source, provide a link to the Creative Commons licence, and indicate if changes were made. The images or other third party material in this article are included in the article's Creative Commons licence, unless indicated otherwise in a credit line to the material. If material is not included in the article's Creative Commons licence and your intended use is not permitted by statutory regulation or exceeds the permitted use, you will need to obtain permission directly from the copyright holder. To view a copy of this licence, visit http://creativecommons.org/licenses/by/4.0/. The Creative Commons Public Domain Dedication waiver (http://creativecommons.org/publicdomain/zero/1.0/) applies to the data made available in this article, unless otherwise stated in a credit line to the data. 

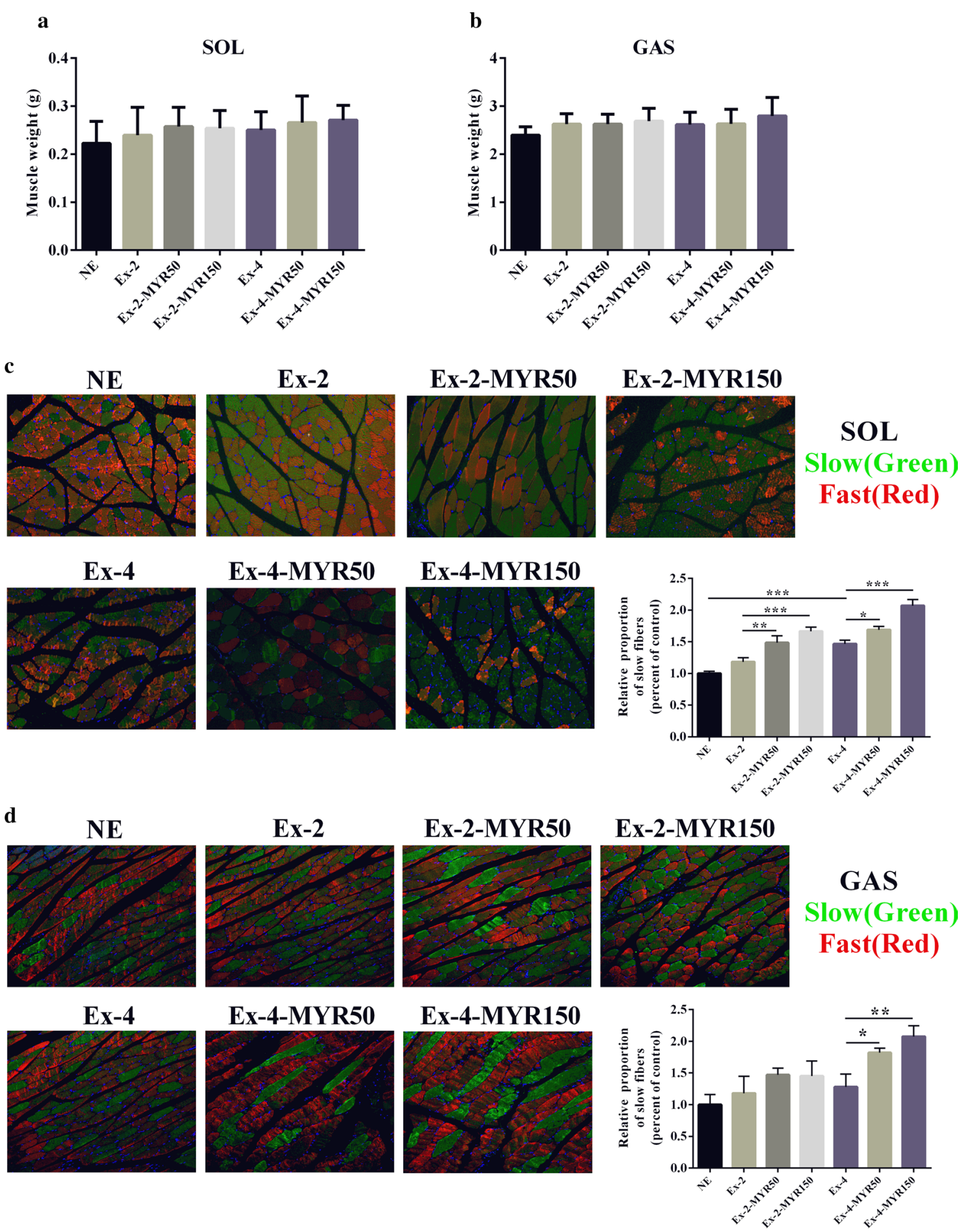

Fig. 2 The effects of myricetin on the formation of slow muscle fibers in vivo. Soleus (a) and gastrocnemius (b) muscle mass was detected at the end of experiment. Soleus (c) and gastrocnemius (d) muscle phenotypes were shown by immunofluorescent staining. Data are presented as mean \pm SD. ${ }^{*} P<0.05,{ }^{* *} P<0.01,{ }^{* *} P<0.001$ 

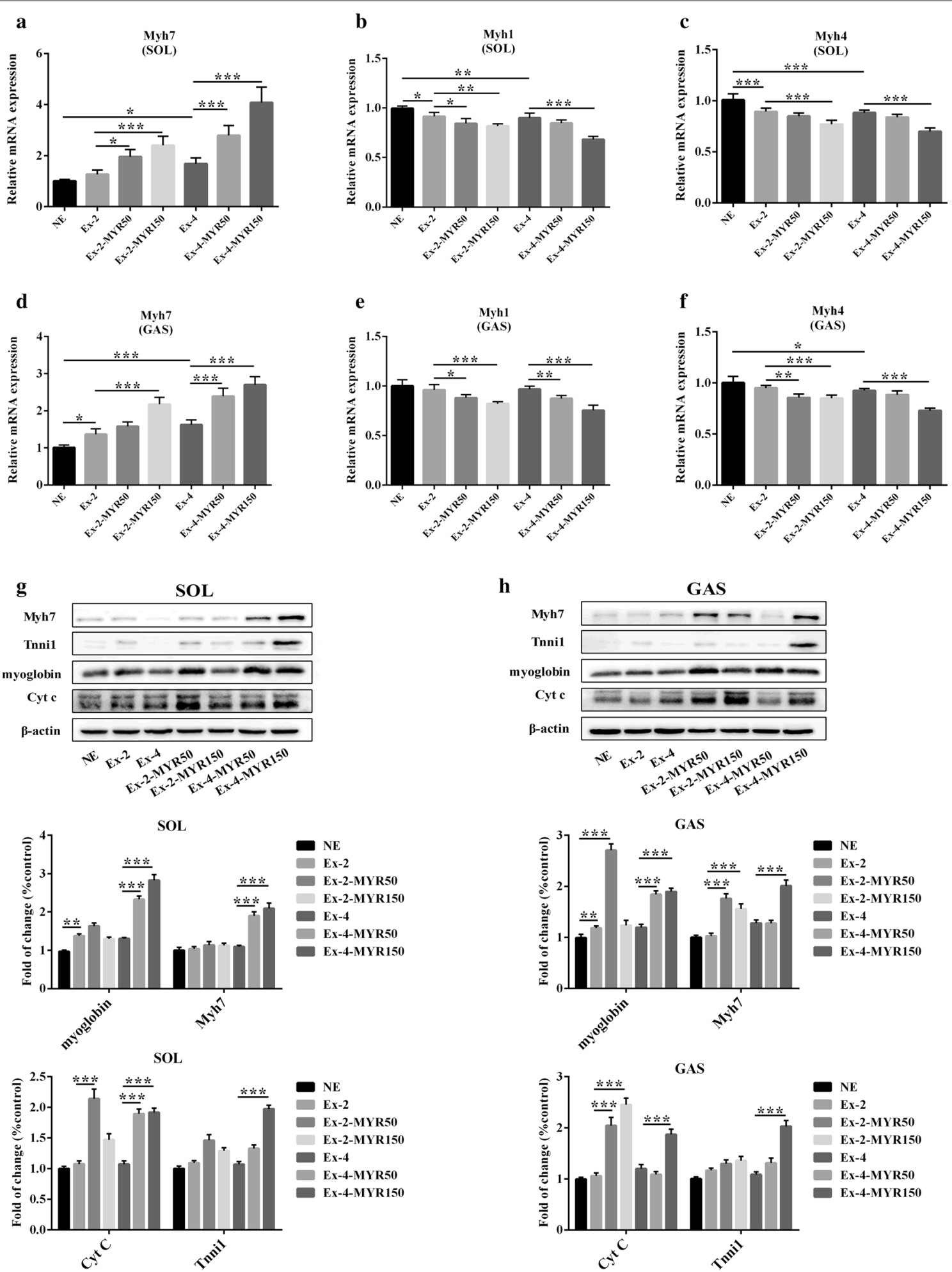

Fig. 3 The effects of myricetin on mRNA and protein expressions of slow twitch-specific in vivo. The mRNA levels of slow-twitch myosin Myh7 (a) and fast-twitch myosin Myh1 (b), Myh4 (c) in soleus and gastrocnemius (d-f) were determined by Real-time PCR. Protein levels of slow-twitch myosin Myh7 and slow-twitch fiber biomarkers in SOL $(\mathbf{g})$ and GAS (h) were measured by immunoblotting. Data are presented as mean \pm SD. ${ }^{*} P<0.05,{ }^{* *} P<0.01,{ }^{* * *} P<0.001$ 


\section{Reference}

1. Wu $L$, et al. Myricetin improves endurance capacity by inducing muscle fiber type conversion via miR-499. Nutr Metab. 2019;16:27. https://doi. org/10.1186/s12986-019-0353-8.

\section{Publisher's Note}

Springer Nature remains neutral with regard to jurisdictional claims in published maps and institutional affiliations. 